\title{
Gender Consumption, Microbial Profile and Potential Risk of Hot Beverages of Coffee, Tea, Milk or Cocoa Sold by Street Vendors in Abidjan, Côte d'Ivoire
}

\author{
Atobla Koua $^{1^{*}} \quad$ Blé Yatanan Casimir $^{2} \quad$ Kouamé N'zebo Désiré $^{1} \quad$ Benié Comoé Koffi Donatien $^{1}$ \\ Adjehi Dadié ${ }^{3}$ Niamké Sébastien ${ }^{1}$ \\ 1.Laboratory of Biotechnologies, Department of Biosciences, Felix Houphouet-Boigny University, 22 BP 582 \\ Abidjan 22, Côte d'Ivoire \\ 2.Department of Agronomic Forest and Environmental Engineering, University of Man, BP 20 Man, Côte \\ d'Ivoire \\ 3.Department of Food Sciences and Technologies (STA), Laboratory of Microbiology and Biotechnology, \\ Nangui Abrogoua University, 02 BP 801 Abidjan 02, Côte d'Ivoire
}

\begin{abstract}
Street hot beverages are increasingly consumed in Côte d'Ivoire. However, there is little data on consumption and contaminants involved in the preparation of these beverages. Thus, this study aimed to contribute to the sanitary quality of hot beverages sold in street. The study assesses the motivation of hot beverages gender consumption and the profile of some contaminants of ready-to-drink hot beverages made of tea, coffee, milk or cocoa from street vendors. Hot beverage consumers were interviewed via a questionnaire and ready-to-drink hot beverages were collected and analyzed biochemically and microbiologically with conventional methods. Thus, 431 samples of these beverages were aseptically collected from five locations of Abidjan city. The survey was conducted among 1448 hot beverage consumers including 1149 males (80\%) and 289 females (20\%). The results showed that males $(38.7 \%)$ consumed more coffee and females $(45.7 \%)$ consumed more tea. Females $(27.3 \%)$ consumed hot beverages for pleasure while males $(27.4 \%)$ consumed them as stimulants. Hot beverages consumers reported symptoms of diarrhea, nausea, dizziness and hand tremors which could link to beverage consumption. The results of the investigation and the enumeration of microbial showed risks associated with the methods of preparing beverages with ingredients. Staphylococcus aureus, Bacillus cereus, Enterobacteria, yeasts and molds strains were enumerated from beverage samples. The tea with its ingredients (sugar, lemon or mint) were the most contaminated sample and coffee was least contaminated. The results of the survey showed a potential health risk linked to preparation methods, the type of beverages mainly tea with ingredients.

Keywords: Street hot beverages, gender consumption, microbial contamination, sanitary quality

DOI: $10.7176 / \mathrm{FSQM} / 105-05$

Received date: December 27, 2020 ; Revised date: January 31, 2021 ; Accepted date: February 27, 2021. Publication date: February 28, 2021

\section{INTRODUCTION}

Street foods are defined as ready to eat food or drink /beverages sold on the street, in a market, fair, park or other public place or food available in a public place, such as from a vendor on a street. It is sold by a vendor from a street on a portable food booth, food cart and a portable stall, cart or food truck meant for immediate consumption (Mohammedsani \& Abrar 2020). According to several authors, street foods are highly appreciated by consumers due to their flavors, attractive, diverse, convenient, low cost, cultural and social heritage links (Chukuezi 2010; Aluko et al. 2014; da Silva et al. 2014). Thus, several studies have shown that street food use raw materials and ingredients of poor microbiological quality because nonauthorized person are involved in the sector of activity (Bereda et al. 2016; Idowu et al. 2006; Rane 2011). In both developing countries and developed countries, street foods generate employment opportunities, especially for low- or uneducated people (Atobla et al. 2020a; Khairuzzaman et al. 2014).

Today, coffee is among the most widely consumed pharmacologically active beverages, and its consumption has become a regular part of daily life worldwide. It is estimated that more than half of Americans drink coffee every day. The average consumption for a person in the European Community is $5.1 \mathrm{~kg} / \mathrm{year}$, which is similar to that in the United States (Bonita et al. 2007). People drink coffee for different reasons, and these reasons may differ between males and females. Both tea and coffee have been demonstrated to improve acute attention (Quinlan et al. 2000, De Bruin et al. 2011), subjective alertness, and psychomotor performance (Hindmarch et al. 2000). In their natural forms, coffee and tea contain several chemical components that may confer both beneficial and adverse health effects, including caffeine and antioxidants (Grigg 2002). Bovine milk and dairy products have been part of the human diet, from birth to old age (McCusker 2003). Farm characteristics and hygienic practices significantly affect milk products quality (Ludwig et al. 2014). Some studies also showed that such drinks may be consumed by young adults, teenagers, college students, athletes, and
\end{abstract}


military personnel (Atanassova et al. 2001; Haeghebaert et al. 2002; Barber et al. 2003).

Food contamination remains a real and permanent risk, especially in cities where this risk is closely linked to the consumption of ready to eat street foods (Akhtar et al. 2012). Various studies have identified the sources of food safety issues involved in street foods to be microorganism belonging to the genus Bacillus, Staphylococcus, Clostridium, Vibrio, Campylobacter, Listeria, Salmonella (Rane 2011). These pathogens, among others, may result in foodborne infections and intoxications once contaminated food is ingested by the unsuspecting consumers. Street foods are often prepared by hand which may lead to an increased incidence of contamination with the potential foodborne pathogens (Rane 2011; Kharel et al. 2016). The bacteria involved in community food poisonings are frequently isolated from the manufacturer's processing, transport and sales environment (Atanassova et al. 2001; Haeghebaert et al. 2002).

Across the world and specifically in Africa, several countries have experienced episodes of poisoning linked to the consumption of street food (Aboagye et al. 2020; Kouassi et al. 2018). Among these street foods, hot street beverages are increasingly consumed in Côte d'Ivoire. Therefore, many people start and end their day with a cup of hot beverages such as tea, coffee, milk or cocoa. In many other countries and in particular in Côte d'Ivoire, there is little data on the consumption, practices and contaminants of hot drinks. Therefore, this study investigated the consumption of these hot beverages in Côte d'Ivoire and determined the contaminants involved in its preparation in order to contribute to the sanity quality of hot beverages sold in street.

\section{MATERIALS AND METHODS}

\subsection{Sampling Sites}

The study was carried out from December 2019 to May 2020 in five communes of Abidjan (Abobo, Adjamé, Yopougon, Cocody and Port-Bouet). Data collection was based on questions asked to 1,448 consumers, volunteer and vendors of hot beverages with hand mobile carts. Verbal consent was obtained from each participant after informing them about the aim of the study according to Atobla et al. (2020b).

\subsection{Sample Collection}

The ready-to-drink beverage samples used for this study were collected from streets and areas of these communes. In these communes, different sample collection points were selected to collect samples. Five kind of ready-to-drink beverages (coffee, tea, milk, coffee with milk or cocoa) sold in street were collected for analysis. A total of 431 samples of hot beverage made of tea, coffee, milk or cocoa were collected in sterile tubes (Table 1). Once collected, beverage samples were carried the same day (within 2 hours) at laboratory of food Microbiology and Biotechnology of Nangui Abrogoua University for microbial analysis.

\begin{tabular}{|c|c|c|c|c|c|c|}
\hline Communes & Tea & Coffee & Milk & Coffee with milk & Cocoa & Total \\
\hline Abobo & 28 & 26 & 14 & 9 & 6 & 83 \\
\hline Adjamé & 28 & 26 & 15 & 11 & 3 & 83 \\
\hline Yopougon & 27 & 29 & 18 & 9 & 10 & 93 \\
\hline Cocody & 27 & 29 & 16 & 9 & 7 & 88 \\
\hline Port-Bouët & 28 & 29 & 13 & 9 & 5 & 84 \\
\hline Total & 138 & 139 & 76 & 47 & 31 & 431 \\
\hline
\end{tabular}

\subsection{Microbial Analysis}

According to the prescriptions of the standards used, one milliliter $(1 \mathrm{~mL})$ of the diluted beverage sample is aseptically analyzed, transferred to a Petri dish and mixed with the respective agar. After solidification, the dishes were incubated at temperatures as given in the respective standard. Two (2) Petri dishes were inoculated by decimal dilutions. The characteristic colonies according to the different media are then enumerated taking into account the calculation standard (NF/ISO 7218: 2007).

Enumeration of yeasts and molds on Sabouraud Chloramphenicol agar (Biokar Diagnostics, France) was carried out according to the NF/ISO 16212: 2011 standard. All the dishes were then incubated in an oven at 30 ${ }^{\circ} \mathrm{C}$ for 48 hours for the enumeration of yeasts and 5 days for molds. The appearance of white to yellowish colonies would indicate the presence of yeasts. The presence of filamentous colonies indicated the presence of fungi. Colonies identified as yeasts or fungi by their macroscopic aspects and their microscopic observations in the fresh state were purified by striae on Sabouraud agar.

Enumeration of Enterobacteria was carried out on Violet Red Neutral Bile Glucose (VRBG) agar (Bio-Rad) according to ISO standard 21528-2: 2004. These dishes were subsequently incubated in an oven at $37{ }^{\circ} \mathrm{C}$ for 24 to 48 hours. The presence of small colonies $(\leq 0.5 \mathrm{~mm})$ of pink to red colors or colorless colonies could indicate the presence of Enterobacteria. The biochemical characteristics of Enterobacteria were determined according to the method of Le Minor \& Richard (1993).

For the enumeration and identification of Staphylococcus aureus, Chapman agar (Bio-Rad) was used 
according to standard NF V 08014: 1984. The dishes seeded were incubated in an oven at $37{ }^{\circ} \mathrm{C}$ for 24 to 48 hours. The appearance of small colonies surrounding a yellow halo or small colonies could indicate the presence of Staphylococcus. For confirmation of Staphylococcus aureus, microscopic observation, catalase, DNase and coagulase tests were performed. Staphylococcus aureus ATCC 25923, a reference strain was used as a positive control.

A serial dilution was then prepared for the enumeration of Bacillus cereus. Of each dilution step, $1 \mathrm{~mL}$ of the inoculum was aseptically spread over the surface of Mannitol Egg Yolk Polymyxin Agar (MYP Agar), a medium developed by Mossel (Bovermann 2017). The inoculated agar plates were then incubated at $37^{\circ} \mathrm{C}$ for 18-24 h. Following the incubation period, all agar plates were examined for potential B. cereus colonies and enumerated. The bacterial count was based on all presumptive colonies on the selective agar medium (MYP). On MYP agar, presumptive $B$. cereus colonies appeared as rough and dry cultures with a diameter of 2-5 $\mathrm{mm}$. Typical colonies growing on MYP agar plates could thus be identified as B. cereus. After a microscopic observation (Gram-positive, rod-shaped, motile) was carried out, Bacillus colonies were purified on nutritive agar.

\subsection{Enumeration of the Microorganism Load}

The number $\mathrm{N}$ of Colony Forming Units per milliliter of beverage samples $(\mathrm{CFU} / \mathrm{mL})$ from the number of colonies obtained in the Petri dishes is carried out according to standard NF/ISO 7218: 2007.

$\mathrm{N}(\mathrm{CFU} / \mathrm{mL})=\frac{\sum C}{V(n 1+0.1 \mathrm{n} 2) \mathrm{d}}$

$-\Sigma \mathrm{C}=$ sum of all characteristic colonies enumerated on all retained Petri dishes from the same sample;

$-\mathrm{V}=$ inoculum volume (volume of sample taken) applied to each dish $(\mathrm{mL})$;

$-\mathrm{n} 1=$ number of Petri dishes retained at the first dilution;

$-\mathrm{n} 2=$ number of Petri dishes retained at the second dilution;

$-\mathrm{d}=$ dilution rate of the first dilution.

\subsection{Estimation of Risk Factors}

The potential risk factors that could justify the level of contamination of the samples and the symptoms reported during the survey were listed based on direct observations and statements made by consumers.

\subsection{Data Analysis}

The data obtained from the questionnaire and observation checklists were analysed using SPSS version 25.0 software, and then exported to Microsoft Excel to calculate the various scores. Descriptive statistics were used to summarise the variables of interest and determine relationships between them. The results were expressed as mean \pm standard deviations $( \pm \mathrm{SD})$, frequencies, and percentages. The Chi-square test was used to test then relationships between the variables. Test of Kruskal Wallis was used to compare bacterial load from different hot beverages. The difference between the variables was considered significant at $\mathrm{p}<0.05$.

\section{RESULTS}

\subsection{Distribution of Beverage Consumption}

According to Table 2, the beverages studied were both consumed by males and females. However, males $(38.7 \%)$ consumed more coffee and females $(45.7 \%)$ consumed more tea. The coffee consumption rate was significantly higher in males $(38.7 \%)$ than in females $(18.0 \%)$. The chi-square test showed that hot beverage consumed by males and females was significantly linked to sex $(\mathrm{p}$-value $=0.001)$.

Table 2. Hot beverage consumption by gender

\begin{tabular}{lll}
\hline \multirow{2}{*}{ Hot beverages } & \multicolumn{2}{c}{ Sex } \\
\cline { 2 - 3 } & $\begin{array}{l}\text { Males }(\mathbf{n}=\mathbf{1 1 5 9}) \\
\text { No. }(\%)\end{array}$ & $\begin{array}{l}\text { Females (n= 289) } \\
\text { No. }(\%)\end{array}$ \\
\hline Coffee & $449(38.7)$ & $52(18.0)$ \\
Tea & $431(37.2)$ & $132(45.7)$ \\
Milk & $123(10.6)$ & $31(10.7)$ \\
Cocoa & $26(2.2)$ & $15(5.2)$ \\
Coffee with milk & $130(11.2)$ & $59(20.4)$ \\
\hline
\end{tabular}

\subsection{Reasons of Hot Beverage Consumption}

Several reasons have been mentioned for the consumption of hot beverages from street vendors. Males consumed hot beverages at $27.4 \%$ as stimulant, while in females the main reason was for pleasure (27.3\%). Also, females $(15.6 \%)$ consumed beverages as stimulant reasons (Table 3$)$. The reasons of hot beverage consumed by 
gender was linked to sex $(p$-value $=0.003)$.

Table 3. Reasons of hot beverage consumption by sex

\begin{tabular}{lll}
\hline Reasons of hot beverage consumption & $\begin{array}{l}\text { Males }(\mathbf{n}=\mathbf{1 1 5 9}) \\
\text { No. }(\mathbf{\%})\end{array}$ & $\begin{array}{l}\text { Females }(\mathbf{n}=\mathbf{2 8 9}) \\
\text { No. }(\mathbf{\%})\end{array}$ \\
\hline For pleasure & $244(21.1)$ & $79(27.3)$ \\
For heath & $102(8.8)$ & $20(6.9)$ \\
For digestion & $63(5.4)$ & $20(6.9)$ \\
As stimulant & $318(27.4)$ & $45(15.6)$ \\
Against hunger & $146(12.6)$ & $37(12.8)$ \\
Against thirsty & $18(1.6)$ & $183(12.6)$ \\
Against cold & $79(6.8)$ & $18(6.2)$ \\
Against tiredness & $106(9.1)$ & $25(8.7)$ \\
Against sleep & $51(4.4)$ & $14(4.8)$ \\
To lose weight & $23(2.0)$ & $16(5.5)$ \\
By habit & $9(0.8)$ & $8(2.8)$ \\
\hline
\end{tabular}

\subsection{Distribution of Consumption Location of Street Hot Beverages}

"Street crossroads" were the places where hot beverages were more consumed for both males $(53.2 \%)$ and female $(50.5 \%)$. It is followed by "Near markets" in female $(18.7 \%)$ but in male level, $15.9 \%$ consumed beverages at "Near car station or bus terminals" (Table 4). The chi-square test showed that location of hot beverage consumption was not significantly linked to sex ( $p$-value $=0.115$ ).

Table 4. Distribution of consumption location

\begin{tabular}{lll}
\hline & \multicolumn{1}{c}{ Sex } \\
\cline { 2 - 3 } Location of street vendors & $\begin{array}{l}\text { Males }(\mathbf{n}=\mathbf{1 1 5 9}) \\
\text { No. }(\%)\end{array}$ & $\begin{array}{l}\text { Females }(\mathbf{n}=\mathbf{2 8 9}) \\
\text { No. }(\%)\end{array}$ \\
\hline Street crossroads & $617(53.2)$ & $146(50.5)$ \\
Near market & $182(15.7)$ & $54(18.7)$ \\
Near car station or bus terminals & $184(15.9)$ & $39(13.5)$ \\
Near school & $86(7.4)$ & $33(11.4)$ \\
Others & $80(7.7)$ & $17(5.8)$ \\
\hline
\end{tabular}

\subsection{Distribution of Number of Cup Consumption}

One (1) cup of hot beverage per day was the highest consumption for both males $(42.9 \%)$ and females $(63.7 \%)$. Table 5 mentioned also that females do not exceed more than 4 cups per day while males go beyond 4 cups per day. The difference was significant between number of cup and the sex ( $p$-value $=0.002$ ).

Table 5. Gender difference regarding to number of cup consumption

\begin{tabular}{lll}
\hline & \multicolumn{1}{c}{ Sex } \\
\cline { 2 - 3 } Number of cups per day & $\begin{array}{l}\text { Males }(\mathbf{n}=\mathbf{1 1 5 9}) \\
\text { No. }(\%)\end{array}$ & $\begin{array}{l}\text { Females }(\mathbf{n}=\mathbf{2 8 9}) \\
\text { No. }(\%)\end{array}$ \\
\hline 1 cup & $403(42.9)$ & $102(63.7)$ \\
2 cups & $357(38.0)$ & $45(28.1)$ \\
3 cups & $146(15.5)$ & $12(7.5)$ \\
4 cups & $23(2.4)$ & $1(0.6)$ \\
5 cups & $9(1)$ & $0(0.0)$ \\
$\geq 6$ cups & $1(0.1)$ & $0(0.0)$ \\
\hline
\end{tabular}

\subsection{Distribution of Symptoms of Disease}

The symptoms suggestive of a probable infection after consuming hot beverages are multiple. Consumers surveyed reported many symptoms of disease such as vomiting, nausea and diarrhea after drinking hot beverages from street beverage vendors with coffee carts (Table 6). According to Table 6, in males the highest symptom was vomiting with a rate of $21.2 \%$ while in females it was nausea that appears the most with a rate of $30.8 \%$. In males after vomiting, follow diarrhea with a rate of $15.4 \%$, while in females after nausea follow vomiting $(23.1 \%)$. The appearance of the symptoms reported in this study was not linked to the gender of consumers $(\mathrm{p}-$ value $=0.676$ ) 
Table 6. Distribution of symptoms of disease

\begin{tabular}{lll}
\hline & Males $(\mathbf{n}=\mathbf{1 1 5 9})$ & Females $(\mathbf{n}=\mathbf{2 8 9})$ \\
Symptoms of disease & No. $(\mathbf{\%})$ & No. $(\%)$ \\
\hline Vomiting & $11(21.2)$ & $3(23.1)$ \\
Diarrhea & $8(15.4)$ & $2(15.4)$ \\
Nausea & $5(9.6)$ & $4(30.8)$ \\
Fever & $2(1.9)$ & $1(7.7)$ \\
Vertigo & $7(13.5)$ & $1(7.7)$ \\
Hand tremors & $6(11.5)$ & $0(0.0)$ \\
Addiction & $2(3.8)$ & $0(0.0)$ \\
Abdominal pain & $5(9.6)$ & $1(7.7)$ \\
Ulcer & $1(1.9)$ & $0(0.0)$ \\
Bloated stomach & $2(3.1)$ & $1(7.7)$ \\
Insomnia & $3(5.8)$ & $0(0.0)$ \\
Headache & $1(1.9)$ & $0(0.0)$ \\
\hline
\end{tabular}

3.6 Estimation of Levels of Microbial Contamination

Microbiological analysis was used to quantify the microbial load in colony-forming units (Table 7). Thus, Staphylococcus aureus were more enumerated in tea $(13.50 \pm 0.30 \mathrm{CFU} / \mathrm{ml})$ and in milk $(12.7 \pm 0.40 \mathrm{CFU} / \mathrm{ml})$. No Staphylococcus aureus and Enterobacteria were isolated from coffee beverage. Bacillus cereus $(10.25 \pm$ $0.32 \mathrm{a} \mathrm{CFU} / \mathrm{ml})$ also were more prevalent in tea. Enterobacteria strains were more prevalent in tea $(7.26 \pm 0.41$ $\mathrm{CFU} / \mathrm{ml})$ and in milk $(7.37 \pm 0.54 \mathrm{CFU} / \mathrm{ml})$. Yeasts and molds were more enumerated in tea $(17.51 \pm 0.2 \mathrm{CFU} / \mathrm{ml})$ and in coffee $(14.40 \pm 0.44 \mathrm{CFU} / \mathrm{ml})$.

Table 7. Microorganism concentrations isolated from hot beverage samples

\begin{tabular}{lllll}
$\begin{array}{c}\text { Numeration } \\
\text { microorganism }\end{array}$ & $\begin{array}{c}\text { of } \\
\text { Staphylococcus } \\
\text { Hot Beverages }\end{array}$ & $\begin{array}{l}\text { Bacillus cereus } \\
\text { (CFU/ml) }\end{array}$ & $\begin{array}{l}\text { Enterobacteriaceae } \\
\text { (CFU/ml) }\end{array}$ & $\begin{array}{l}\text { Yeasts } \\
\text { molds } \\
\text { (CFU/ml) }\end{array}$ \\
\hline Tea & $13.50 \pm 0.30 \mathrm{a}$ & $10.25 \pm 0.32 \mathrm{a}$ & $7.26 \pm 0.41 \mathrm{a}$ & $17.51 \pm 0.26 \mathrm{a}$ \\
Coffee & $0.0 \mathrm{~b}$ & $6.25 \pm 0.28 \mathrm{abc}$ & $0.0 \mathrm{~b}$ & $14.40 \pm 0.44 \mathrm{ab}$ \\
Milk & $12.7 \pm 0.40 \mathrm{a}$ & $8.17 \pm 0.28 \mathrm{ab}$ & $7.37 \pm 0.54 \mathrm{a}$ & $5.43 \pm 0.32 \mathrm{bc}$ \\
Coffee with milk & $7.31 \pm 0.25 \mathrm{ab}$ & $4.43 \pm 0.32 \mathrm{bc}$ & $5.31 \pm 0.24 \mathrm{ab}$ & $9.12 \pm 0.15 \mathrm{ab}$ \\
Cocoa & $0.26 \pm 0.04 \mathrm{cb}$ & $3.38 \pm 0.18 \mathrm{c}$ & $2.22 \pm 0.26 \mathrm{ab}$ & $4.32 \pm 0.16 \mathrm{c}$ \\
\hline
\end{tabular}

The values in the same column with similar superscripts are not significantly different from each other $(\mathrm{p}>$ $0.05)$.

\subsection{Health Risk Factors}

The health risk survey revealed several categories of information depending on the investigated parameters (Table 8). Thus, the active population was exposed to the risk of foodborne illness. After street beverage consumption, the risks of infection occurred varying according different factors such as consumer ages, education, type of beverages, number of cups consumed per day, ingredients, materials used and other risks. Also, the highest factor risks were recorded through the handling of products, materials or ingredients. The cooking process was also one of the determining factors linked to the beverage poisoning risks. In addition, a supplement contamination factor was the water used to prepare and rinse recyclable cup. Hot beverage contamination varied according to several factors. 
Table 8 . Potential risk of contamination related to beverage consumption sold by street vendors

\begin{tabular}{|c|c|c|}
\hline & Category & $\begin{array}{r}\text { Potential risk } \\
\text { Factors }\end{array}$ \\
\hline Number of cups consumed & $\begin{array}{l}1 \text { cup, } 2 \text { cups, } 3 \text { cups, } 4 \text { cups, } 5 \text { cups } \\
\geq 6 \text { cups }\end{array}$ & $\begin{array}{c}+ \\
++ \\
\end{array}$ \\
\hline $\begin{array}{l}\text { Place of preparation, sellin } \\
\text { consumption }\end{array}$ & $\begin{array}{l}\text { IStreet corner or street crossroads, market, car station or } \\
\text { bus terminals, near school }\end{array}$ & + \\
\hline Ingredients & Sugar, Lemon, Mint or milk & ++ \\
\hline Materials & $\begin{array}{l}\text { Thermos for hot water, Spoon, Knife, Scissors, } \\
\text { Lemon squeezer }\end{array}$ & $\begin{array}{c}++ \\
++ \\
+\end{array}$ \\
\hline Others risks & $\begin{array}{l}\text { Water used to prepare and rinse recyclable cups } \\
\text { Disposable cups } \\
\text { Recyclable cups } \\
\text { Ingredients } \\
\text { Handling of products, materials or adding ingredients } \\
\text { Beverage cooking process } \\
\text { Hygiene of vendors } \\
\text { Dose (excess), Taste }\end{array}$ & $\begin{array}{l}+++ \\
+ \\
++ \\
++ \\
+++ \\
++ \\
++ \\
+\end{array}$ \\
\hline
\end{tabular}

+ Low risk, ++ Moderate risk, +++ High risk

\section{DISCUSSION}

The survey performed on hot beverage consumption showed that it is an important drink of daily life of many workers in street. Street hot beverages are consumed both by males and females. Coffee consumption rate was significantly higher in males $(38.7 \%)$ than in females $(18.0 \%)$. However, tea consumption rate was higher in females $(45.7 \%)$ than in males $(37.2 \%)$. Other studies reported that males drink more coffee than women. These studies discovered that over $50 \%$ of men drink coffee compared to about just $32 \%$ of women (Demura et al. 2013). Several other reasons could explain this difference. Thus, knowledge about coffee may also differ between males and females. Our study showed that females prefer consuming more tea than males. In contrast, Safila \& Asra (2014) study reported that males consumed more tea than females. In short, it is important to note that the nutrients and digestibility of tea and coffee are factors that influence consumption between males and females. This is why Mirmiran et al. (2010) reported gender as a factor influencing nutrient consumption and Du et al. (2010) demonstrated that females have higher interest in the nutrients than males.

The reasons for drinking hot street beverages differ according to gender. Indeed, the results of our study showed that males at a rate of $27.4 \%$ consumed as stimulant to boost their energy, while $27.3 \%$ of females consumed them for pleasure or against hunger. For Atobla et al. (2020a), coffee or tea offered an energy boost to work. According to Demura et al. (2013), many people who drink coffee expect to feel awake. Many people survey in this study drank coffee for its taste (Demura et al. 2013). Young generations, for example, most college students, consume caffeine to feel more awake, enjoy the taste, socialize, increase their physical energy, improve their mood, and alleviate stress (Atobla et al. 2020b; Mahoney et al. 2019).

A rate of $27.4 \%$ of males consumed hot street beverages as a stimulant and $21.1 \%$ for pleasure, while $27.3 \%$ of females consumed them for pleasure and $15.6 \%$ as a stimulant. This variation in consumption reasons influences the number of cups per day. Indeed, according to our survey, both males $(42.9 \%)$ and females $(63.7 \%)$ consumed mostly one cup per day. In addition, $38 \%$ of males consumed two (2) cups per day while $28.1 \%$ of females consumed two (2) cups per day. Our results revealed that males consumed more cups per day than females. According to Safila \& Asra (2014), tea consumption is prevalent among all age groups and 2-3 cups of tea is the mostly consumed amount of tea. Based on the data reviewed, it can be concluded that for the healthy adult population, moderate caffeine intake (2-3 cups or $300 \mathrm{mg} /$ day) is not associated with adverse effects, such as cardiovascular effects, changes in adult behavior and effects on male fertility (Nawrot et al. 2003). The Korean National Health and Nutrition Examination Survey reported that the prevalence of daily coffee drinking ( 1 or more cups/day) greatly increased from 54.6\% in 2001 to $65.3 \%$ in 2010-2011 among Korean adults (Je et al. 2014). Many studies show that coffee consumption may help prevent several chronic diseases. In particular, long-term coffee consumption is associated with significant dose-dependent reductions in the risk of developing type 2 diabetes (Nawrot et al. 2003). In addition, coffee contains several physiologically active substances; caffeine, in particular, is an important component of coffee (Ludwig et al. 2014; Heckman et al. 2010). It is found in common beverages (coffee, tea, soft drinks), in products containing cocoa or chocolate, and in medications (Nawrot et al. 2003). For Heckman et al. (2010), the total daily intake, as well as the major source of caffeine varies globally; however, coffee and tea are the 2 most prominent sources.

Our study showed that $53.2 \%$ of males and $50.5 \%$ of females questioned consumed hot street beverages in the street crossroad. Furthermore, the distribution of disease symptoms during our study showed that $21.2 \%$ of 
males reported vomiting, $15.4 \%$ diarrhea while $30.8 \%$ of females reported nausea and $23.1 \%$ vomiting after consuming hot beverages in some cases. The main causes of these symptoms could be the presence of microorganisms reported in our study. Indeed, our study reported the presence of Staphylococcus aureus, Bacillus cereus, Enterobacteria and yeasts and molds in ready-to-drink beverages. Even if the difference of each germ is not significant in the different beverages, it should be noted the absence of Staphylococcus aureus and Enterobacteria in coffee in our study. Across the world and specifically in Africa, several countries have experienced episodes of food poisoning without scientifically proofed of given food involvement. In Côte d'Ivoire and many others countries, there are few reports in the literature on the hot beverage contaminant: a few studies have been done on the presence of microorganisms in street hot beverages. Hot beverage contamination varied according to several factors. In our study, no $S$. aureus and Enterobacteria have been isolated from coffee beverage. The antibacterial effect of coffee has been demonstrated in various studies carried out over the past 15 years (Gov et al. 2010), showing that growth of certain bacteria was either inhibited or stunted by different concentrations of coffee extract. For example, the growth of Gram-negative bacteria Escherichia coli, Salmonella typhi and Pseudomonas aeruginosa and Gram-positive bacteria Staphylococcus aureus, Bacillus cereus, Lactobacillus bulgaricus, Streptococcus lactis and S. faecalis were inhibited (Fardiaz 1995), and in addition to that, decreases in bacterial growth were observed in L. bulgaricus, E. coli, S. typhi and S. faecalis. A report showed that pure caffeine has a direct antibacterial effect (Ramanaviciene et al. 2003). According to the study of Giannotti et al. (2002) and European Commisions (2011), coffee contains the highest amount of caffeine (40-259 mg) among foods and beverages, followed by teas (30-80 mg), and chocolate products (12-25 $\mathrm{mg})$.

In our study, Bacillus were also isolated from hot beverage samples. Among Bacillus species, Bacillus cereus is widespread in nature and readily found in soil, where it adopts a saprophytic life cycle; germinating, growing and sporulating in this environment. Murindamombe et al. (2005) and Vilain et al. (2006) also reported the incidence of Bacillus cereus in street foods in Botswana and from Biltong respectively. The presence of different species of Bacillus spp. in this study might be explained by the fact that most of the meat samples were exposed to dust and flies as observed during the observational study (Tshipamba et al. 2018). According to the European Food Safety Authority (EFSA), contamination levels below $100 \mathrm{CFU} / \mathrm{g}$ are not unusual. Introduction of $B$. cereus at such low concentrations into other foods via contaminated source material, such as spices or milk powder, does not pose a health risk as defined by consumer health protection regulations (EFSA 2005).

The presence of Staphylococcus aureus in hot beverages in this study revealed an unacceptable state of poor hygienic and sanitary practices during the preparation of the foods, which can be linked with the results of the observation study which revealed poor hygienic practices by vendors. The findings of Sina et al. (2011) and Mensah et al. (2002) who reported that poor hygienic practices and poor food handling could result in the occurrence of Staphylococcus aureus agree with the result of this research where the incidence of Staphylococcus aureus is recurrent in all the street vended food.

After street beverage consumption, the risks of infection could occur varying according different factors according to our study. Thus, the highest factor risks were recorded through the water used to prepare and rinse recyclable cups, handling of products, materials or ingredients. Several studies have shown that street food use raw materials and ingredients of poor microbiological quality because nonauthorized person are involved in this sector of activity (Atobla et al. 2020a; Bereda et al. 2016; Rane 2011). According to Rane (2011), major sources contributing to microbial contamination are the place of preparation, utensils for cooking and serving, raw materials, time and temperature abuse of cooked foods and the personal hygiene of vendors. The cooking process is also one of the determining factors linked to the beverage poisoning risks as reported in our study. Liu et al. (2014) explained that poor quality of raw materials, improper food preparation and lack of awareness about food safety are possibly the most common cause of food poisoning outbreaks. Also, the lack of hygiene of the seller, the sales environment, the sales equipment, the water used; the breaking of the cold chain and bad handling are all factors that favor the contamination of street foods, especially energy drinks made from tea and coffee. In addition, a supplement contamination factor is the water used to prepare and rinse recyclable cup. That is why, across the world and specifically in Africa, several countries have experienced episodes of poisoning linked to the consumption of street food. According to Proietti et al. (2014), street foods are at a risk of getting contaminated by air pollutants (they are mainly sold in the open, often alongside streets), contaminated raw material from unsafe sources. For Feglo \& Sakyi (2012), contamination of food in most developing countries is as a result of several factors such as, methods applied in processing foods, inadequate storage temperatures and poor personal hygiene of food handlers. Nasiruddin (2019) reported that today millions of people catch diseases originating from food sources and thousands of deaths occur in world. The wide consumption of street food around the world increase the importance of safety and health issues (Ceyhun Sezgin \& Şanlier 2016). Street foods are not reliable, they also carry diseases originating from food sources in many countries (Biswas et al. 2010; Omemu \& Aderoju 2008). The presence of potential pathogenic strains in beverage could be as result of poor hygiene practice of food vendors and could constitute a health risk to consumers, so education of street 
vendors is essential in maintaining hygiene and hence safety of food.

\section{Conclusion}

The study showed that females consumed hot street beverages for pleasure while males consume them as stimulants to boost energy. Coffee was consumed more by males and tea more appreciated by females. Readyto-drink hot beverage contamination varied according to several factors such as handling of products, materials or adding ingredients. The investigation showed that the presence of potentially pathogenic strains in beverages could be due to poor hygiene practices of vendors which could constitute a risk to the health of consumers. The data collected as part of this study should provide sufficient motivation to remain conscious of potential health risks due to poor hygiene, in particular in street foods consumption. The practice of hygiene rules and good sanitary management of the production chain of these types of beverages could reduce the risk of contamination. Furthermore, consumer's knowledge and attitude may influence food safety behavior and practice.

\section{Acknowledgements}

The authors thank street beverage vendors with coffee carts. This work was supported by ASCAD (Académie des Sciences, des Arts, des Cultures d'Afrique et des Diasporas Africaines) funds.

\section{Conflict of Interests}

The authors have not declared any conflict of interests

\section{REFERENCES}

Aboagye, G., Gbolonyo-Cass, S., Kortei, N.K. \& Annan, T. (2020), "Microbial evaluation and some proposed good manufacturing practices of locally prepared malted corn drink ("asaana") and Hibiscus sabdarifa calyxes extract ("sobolo") beverages sold at a university cafeteria in Ghana" Scientific African 8 (2020) e00330.

Akhtar, S., Sarker, M.R. \& Hossain, A. (2012), "Microbiological Food Safety: A Dilemma of Developing Societies", Critical Reviews in Microbiology 40(4), 348-359.

Aluko, O.O., Ojeremi, T.T., Olaleke, D.A. \& Ajidagba, E.B. (2014), "Evaluation of food safety and sanitary practice among food vendors at car parks in Ile Ife, southwestern Nigeria", Food Control 40(1), 165-171.

Atanassova,V., Meindl, A. \& Ring C. (2001), "Prevalence Of Staphylococcus aureus And Staphylococcal Enterotoxins In Rawpork And Uncooked Smoked Ham A Comparison Of Classical Culturing Detection And RFLP-PCR", International Journal of Food Microbiology 68(1-2), 105-113.

Atobla, K., Kouadio-Ngbesso, N., Oumarou, T.F., Dadié, A. \& Niamké, S. (2020b), "Safety Assessment of Street Hot Beverages Made of Coffee, Tea, Milk or Cocoa Consumed in Abidjan City" American Journal of Food and Nutrition 8 (2), 23-31.

Atobla, K., Touré, N., Koffi A.R., Oumarou, T.F., Kouadio-Ngbesso, N., Dadié, A. \& Niamké, S. (2020a), "Practices and Attitudes Assessment of Street Vendors of Hot Beverages Made of Coffee, Tea, Milk or Cocoa with Coffee Carts", Journal of Food Security 8 (2), 43-51.

Barber, D.A., Miller, G.Y. \& McNamara, P.E. (2003), "Models Of Antimicrobial Resistance And Foodborne Illness: Examining Assumptions And Practical Applications", Journal of Food Protection 66 (4), 700-709.

Bereda, T.W., Emerie, Y.M., Reta, M.A. \& Asfaw, H.S. (2016), "Microbiological Safety Of Street Vended Foods In Jigjiga City, Eastern Ethiopia", Ethiopian Journal of Health Science 26(2), 161-170.

Biswas, S., Parvez, M.A.K., Shafiquzzaman, M., Nahar, S. \& Rahman, M.N. (2010), "Isolation and characterization of Escherichia coli in ready-to-eat foods vended in Islamic University, Kushtia" Journal of Bio-Science 18 (1), 99-103.

Bonita, J.S., Mandarano, M., Shuta, D. \& Vinson, J. (2007), "Coffee and cardiovascular disease: in vitro, cellular, animal, and human studies" Pharmacological Research 55 (3), 187-98.

Bovermann, B. (2017), "Bacillus cereus contamination in coffee makers at several Bundeswehr dining and recreational facilities", Wehrmedizinische Monatsschrift 61 (2/3), 42 - 49.

Ceyhun Sezgin, A. \& Şanlier, N. (2016), "Street food consumption in terms of the food safety and health" Journal of Human Sciences 13 (3), 4072-4083.

Chukuezi, C.O. (2010), "Food Safety and Hygienic Practices of Street Food Vendors in Owerri, Nigeria", Studies in Sociology of Science 1 (1), 50-57.

da Silva, S.A., Cardoso RdeC.V., Góes, J.Â.W., Santos, J.N., Ramos, F.P., de Jesus, R.B., do Vale, R.S. \& da Silva, P.S.T. (2014), "Street food on the coast of Salvador, Bahia, Brazil: A study from the socioeconomic and food safety perspectives" Food Control 40, 78-84.

De Bruin, E.A., Rowson, M.J., Van Buren, L., Rycroft, J.A. \& Owen, G.N. (2011), "Black tea improves attention and self-reported alertness" Appetite 56 (2), 235-240.

Demura, S., Aoki, H., Mizusawa, T., Soukura, K., Noda, M. \& Sato T (2013). “Gender Differences in Coffee 
Consumption and Its Effects in Young People", Food and Nutrition Sciences 4 (7), 748-757.

EFSA (2005). European Food Safety Authority. Opinion of the Scientific Panel on biological hazards (BIOHAZ) on B. cereus and other Bacillus spp. in foodstuffs. The EFSA Journal 175, 1 - 48.

EFSA (2015), "EFSA NDA Panel (EFSA Panel on Dietetic Products, Nutrition and Allergies). Scientific opinion on the safety of caffeine", EFSA Journal 13(5), 4102.

Ekanem, E.O. (1998), "The street food trade in Africa: safety and socio-environmental issues" Food Control 9(4), 211-215.

European Commisions (2011). Regulation (EU) No 1169/2011 of the European parliament and of the council of 25 October 2011 on the provision of food information to consumers, amending Regulations (E C) No 1924/2006 and (EC) No 1925/2006 of the of the European Parliament and of the Council, and repealing Commission Directive 87/250/EEC, Council Directive 90/496/EEC, Commission Directive 1 999/ 10/EC, Directive 2000/13/EC of the European Parliament and of the Council, Commission Directives 2002/67/EC and 2008/5/EC and Commission Regulation (EC) No 608/ 2004. In Official Journal of the European Union L304: 18-63.

Fardiaz S (1995)., “Antimicrobial activity of coffee (Coffee robusta) extract”, ASEAN Food Journal 10 (3), 103 106.

Feglo, P. \& Sakyi, K. (2012), "Bacterial contamination of street vending food in Kumasi, Ghana" Journal of Medical and Biomedical Sciences 1 (1), 1-8.

Giannotti, F., Cortesi, F., Sebastiani, T. \& Ottaviano, S. (2002), "Circadian preference, sleep and daytime behaviour in adolescence", Journal of Sleep Research 11 (3), 191-199.

Gov, Y., Sterer, N. \& Rosenberg, M. (2010), "In vitro effect of coffee on oral malodor-related parameters", Journal of Breath Research 4 (2), 1-5.

Grigg, D. (2002), “The worlds of tea and coffee: patterns of consumption”, GeoJournal 57 (4), $283-94$.

Haeghebaert, S., Le Querrec, F., Bouvet, A.P., Gallay, E. \& Vaillant, V. (2002), "Les toxi-Infections alimentaires collectives en France en 2001”, Bulletin Epidemiologique Hebddomadaire BEH n50/2002, 249-253.

Heckman, M.A., Weil, J. \& Gonzalez de Mejia, E. (2010), "Caffeine (1, 3, 7-trimethylxanthine) in foods: a comprehensive review on consumption, functionality, safety, and regulatory matters", Journal of Food Science 75 (3): R77-87.

Hindmarch, I., Rigney, U., Stanley, N., Quinlan, P., Rycroft, J. \& Lane, J. (2000), “A naturalistic investigation of the effects of day-long consumption of tea, coffee and water on alertness, sleep onset and sleep quality", Psychopharmacology 149 (3), 203-216.

Idowu, O. \& Rowland, S. (2006), "Oral Fecal Parasites and Personal Hygiene of Food Handlers in Abeokuta, Nigeria" African Health Sciences 6(3), 160-164.

Je, Y., Jeong, S. \& Park, T. (2014), "Coffee consumption patterns in Korean adults: the Korean National Health and Nutrition Examination Survey (2001-2011)”, Asia Pacific Journal of Clinical Nutrition 23 (4), 691702.

Khairuzzaman, M., Chowdhury, F.M., Zaman, S., Al Mamun, A. \& Bari, M.L. (2014), "Food Safety Challenges towards Safe, Healthy, and Nutritious Street Foods in Bangladesh" International Journal of Food Sciences 2014, (ID. 483519), 9.

Kharel, N., Palni, U. \& Tamang, J.P (2016), "Microbiological assessment of ethnic street foods of the Himalayas", Journal of Ethnic Foods 3 (3), 235-241.

Kouassi, K.C., Voko, D.-R.R.B., Koffi, A.C., Kouame K.B.E.-B. \& Koffi-nevry, R. (2018), "Microbial contamination of the non-alcoholic beverage Gnamakoudji made from Zingiber officinale in Daloa, Côte d'Ivoire", African Journal of Microbiology Research 12(35), 857-865.

Le Minor, L. \& Richard, C. (1993), "Méthodes de laboratoire pour l'identification des Entérobactéries", Commission des laboratoires de références et d'expertise de l'Institut Pasteur, Institut Pasteur, Paris, France. 218 p. 1993.

Liu, Z., Zhang, G. \& Zhang, X. (2014), "Urban street foods in Shijiazhuang city, China, Current status, safety practices and risk mitigating strategies" Food Control 41 (1), 212-218.

Ludwig, I.A., Mena, P., Calani, L., Cid, C., Rio, D.D., Lean, M.E.J. \& Crozier, A. (2014), "Variations in caffeine and chlorogenic acid contents of coffees: what are we drinking?" Food Function 5 (8), 1718-1726.

Mahoney, C.R., Giles, G.E., Marriott, B.P., Judelson, D.A., Glickman, E.L., Geiselman, P.J. \& Lieberman, H.R. (2019), "Intake of caffeine from all sources and reasons for use by college students", Clinical Nutrition 38 (2), 668-675.

McCusker, R.R., Goldberger, B.A., \& Cone E.J. (2003), “Caffeine content of specialty coffees" Journal of Analytical Toxicology 27 (7), 520-522.

Mensah, P., Yeboah-Manu, D., Owusu-Darko, K. \& Ablordey, A. (2002), "Street foods in Accra, Ghana: how safe are they?" Bulletin of the World Health Organization 80 (7), 546-554. 
Mirmiran, P., Mohammadi-Nasrabadi Omidvar, F.N., Hosseini-Esfahani, F., Hamayeli-Mehrabani, H., Mehrabi, Y., Azizi, F. (2010), "Nutritional Knowledge, Attitude and Practice of Tehranian Adults and Their Relation to Serum Lipid and Lipoproteins: Tehran Lipid and Glucose Study, Annals of Nutrition \& Metabolism 56 (3), 233-240.

Mohammedsani, Z.S. \& Abrar, S.M. (2020), "Street Food Consumption and Associated Health Risk" International Journal of Research Studies in Agricultural Sciences 6(7), 8-18,

Murindamombe, G.Y., Collison, E.K., Mpuchane, S.F. \& Gashe, B.A. (2005), "Presence of Bacillus cereus in street foods in Gaborone, Botswana", Journal of Food Protection 68(2), 342-346.

Nasiruddin, K. (2019), "Caffeinated beverages and energy drink: pattern, awareness and health side effects among Omani university students", Biomedical Research 30(1), 113-121.

Nawrot, P, Jordan, S., Eastwood, J., Rotstein, J., Hugenholtz, A. \& Feeley, M. (2003), "Effects of caffeine on human health", Food Additives and Contaminants, 20(1), 1-30.

Omemu, A.M. \& Aderoju, S.T. (2008), "Food Safety Knowledge and Practices of Street Food Vendors in the City of Abeokuta, Nigeria", Food Control 19(4): 396-402.

Proietti, I., Frazzoli, C. \& Mantovani, A. (2014), "Identification and management of toxicological hazards of street foods in developing countries", Food and Chemical Toxicology 63, 143-152.

Quinlan, P.T., Lane, J., Moore, K.L., Aspen, J., Rycroft, J.A. \& O’Brien, D.C. (2000), “The acute physiological and mood effects of tea and coffee: The role of caffeine level", Pharmacology, Biochemistry and Behavior 66 (1), 19-28.

Ramanaviciene, A., Mostovojus, V., Bachmatova, I., Ramanavicius, A. (2003), “Anti-bacterial effect of caffeine on Escherichia coli and Pseudomonas fluorescens", Acta medica Lituanica 10, 185-188.

Rane, S. (2011), "Street Vended Food in Developing World: Hazard Analyses", Indian Journal of Microbiology 51(1), 100-106.

Safila, N. \& Asra, H. (2014), "Consumption of Tea in Professionals and Non-professionals", SOJ Pharmacy \& Pharmaceutical Sciences 1(3), 1-4.

Sina, H, Baba-Moussa F., Kayode, A., Noumavo, P., Sezan, A., Hounhouigan, J.D., Kotchoni, S.O., Prévost, G. \& Baba-Moussa, L. (2011), "Characterization of Staphylococcus aureus isolated from street foods: Toxin profile and prevalence of antibiotic resistance, "Journal of Applied Biosciences 46, 3133-3143.

Tshipamba, M.E., Lubanza, N., Adetunji, M.C. \& Mwanza, M. (2018), "Evaluation of the Effect of Hygiene Practices and Attitudes on the Microbial Quality of Street Vended Meats Sold in Johannesburg, SouthAfrica", Journal of Food Microbiology Safety and Hygiene 3 (2), 137.

Vilain, S., Luo, Y., Hildreth, M.B. \& Brozel, V.S. (2006), "Analysis of the life cycle of the soil saprophyte Bacillus cereus in liquid soil extract and in soil", Applied and Environmental Microbiology 72 (7), 4970 4977. 